Article

\title{
Fumonisin $\mathrm{B}_{1}$ Interaction with $\mathrm{Mg}-\mathrm{Al}$ and $\mathrm{Mg}-\mathrm{Fe}$ Layered Double Hydroxides: Removal Efficiency and Mechanisms
}

\author{
Jakub Matusik ${ }^{1, *(1)}$ and Youjun Deng ${ }^{2}$ \\ 1 Faculty of Geology, Geophysics and Environmental Protection; Department of Mineralogy, Petrography and \\ Geochemistry, AGH University of Science and Technology, al. Mickiewicza 30, 30-059 Krakow, Poland \\ 2 Department of Soil and Crop Sciences, Texas A\&M University, College Station, TX 77843-2474, USA; \\ yjd@tamu.edu \\ * Correspondence: jmatusik@agh.edu.pl; Tel.: +48-126175233
}

Received: 8 September 2020; Accepted: 28 September 2020; Published: 29 September 2020

\begin{abstract}
Mycotoxins in feed and food are highly toxic and pose a serious danger even at very low concentrations. The use of bentonites in animal diet can reduce toxin bioavailability. However, some mycotoxins like fumonisin B1 (FB1) form anionic species which excludes the use of negatively charged clays. Layered double hydroxides (LDH) with anion-exchange properties, in theory, can be perfect candidates to adsorb FB1. However, fundamental research on the use of LDH for mycotoxins removal is scarce and incomplete. Thus, the presented study was designed to explore such a possibility. The LDH materials with differing chemistry and layer charge were synthesized by co-precipitation both from metal nitrates and chlorides and were then tested for FB1 removal. XRD, FTIR, XPS, and chemical analysis were used for the LDH characterization and to obtain insight into the removal mechanisms. A higher adsorption capacity was observed for the $\mathrm{Mg} / \mathrm{Al} \mathrm{LDH}$ samples $(\sim 0.08-0.15 \mathrm{~mol} / \mathrm{kg})$ in comparison to the $\mathrm{Mg} / \mathrm{Fe}$ LDH samples $(\sim 0.05-0.09 \mathrm{~mol} / \mathrm{kg})$ with no difference in removal efficiency between $\mathrm{Cl}$ and $\mathrm{NO}_{3}$ intercalated $\mathrm{LDH}$. The adsorption capacity increased along with lower layer charge of $\mathrm{Mg} / \mathrm{Al}$ and was attributed to the lower content of bonded carbonates and the increase of non-polar sites which led to matching between the adsorption domains of LDH with FB1. The FTIR analysis confirmed the negative effect of carbonates which hampered the adsorption at $\mathrm{pH} 7$ and led to the highest adsorption at $\mathrm{pH} 5$ (FB1 content $\sim 15.8 \pm 0.75 \mathrm{wt} . \%)$. The fast surface adsorption (1-2 $\mathrm{min}$ ) was dominant and XRD analysis of the basal spacing indicated that no FB1 intercalation occurred in the LDH. The XPS confirmed a strong interaction of FB1 with Mg sites of $\mathrm{LDH}$ at $\mathrm{pH} 5$ where the interaction with $\mathrm{FB} 1$ carboxylate moieties $\mathrm{COO}^{-}$was confirmed. The research confirmed a high affinity and selectivity of LDH structures towards anionic forms of FB1 mycotoxin.
\end{abstract}

Keywords: layered double hydroxides; adsorption; fumonisin B1; carbonates; XPS analysis

\section{Introduction}

Mycotoxins are complex organic compounds produced as a result of metabolic processes by filamentous fungi of different genera, e.g., Fusarium, Aspergillus and Penicillium. Currently, there are about 300 known metabolites which have adverse effects on living organisms including animals and humans [1]. The most important classes of mycotoxins that are unwanted in food and feed products are aflatoxins, trichothecenes, zearalenone, ochratoxins, and fumonisins. Most hazardous mycotoxins pose a serious danger even at very low concentrations and have been reported to be highly toxic and carcinogenic [2].

The contamination of food and feed by mycotoxins is a serious global problem that is responsible for significant economic losses. It is estimated that approximately $25 \%$ of all crops worldwide 
contain mycotoxins [1]. The mycotoxins presence is due to fungal infection of crops, particularly observed for cereals, e.g., maize, barley, wheat, rye, and oat. This causes health problems including chronic diseases leading to liver disorders, immunologic effects, digestive disorders, reproductive and metabolic disorders, and even death. The adverse effects of mycotoxins and their negative impact on the food market has led to the development of different prevention and decontamination strategies $[1,3,4]$. One category of approaches includes physical methods (e.g., sorting, separation, washing, or irradiation) and chemical treatment (the use of bases and oxidizing agents). The other category involves decontamination using adsorbents which could be potentially included in the animal diet. Such materials having adsorption properties can reduce toxin bioavailability through their immobilization. These include micro- and nano-sized minerals and non-mineral particles, e.g., clay minerals, zeolites, and activated carbons and their derivatives. Currently, bentonites, which are abundant sedimentary rocks rich in smectite clay minerals, have demonstrated a protective role against aflatoxins [5-9]. However, some mycotoxins are known to form anionic species, e.g., fumonisin $B_{1}$ (FB1) which cannot be efficiently removed by the materials listed above due to their exclusive cation exchange properties. FB1 has a structure containing both basic $-\mathrm{NH}_{2}$ and acidic $-\mathrm{COOH}$ functional groups. Its charge changes as a function of solution $\mathrm{pH}$ and is mostly negative due to $-\mathrm{COOH}$ deprotonation. Therefore, in this study for its removal, a different class of materials was tested, i.e., layered double hydroxides (LDHs), which are also applied in catalysis, polymer chemistry, biomedicine, and wastewater treatment [10-16].

LDHs are crystalline phases classified as non-silicate oxides and hydroxides of the following general chemical formula: $\left[\mathrm{M}^{\mathrm{II}}{ }_{1-\mathrm{x}} \mathrm{M}^{\mathrm{III}}{ }_{\mathrm{x}}(\mathrm{OH})_{2}\right]^{\mathrm{X}+}\left[\left(\mathrm{Am}^{-}\right)_{\mathrm{x} / \mathrm{m}} \cdot \mathrm{nH}_{2} \mathrm{O}\right]^{\mathrm{X}-}$ [17]. The first part of the formula represents a positively charged brucite-like layer containing both di- and trivalent cations ( $\mathrm{M}^{\mathrm{II}}$ and $\left.\mathrm{M}^{\mathrm{III}}\right)$, while the second part shows the interlayer composition where hydrated anions are present. The LDHs show evident similarities to natural clay minerals. These include a layered structure, diverse chemical composition due to isomorphous substitutions, variable layer charge, and rheological and colloidal properties. However, the main difference is their ability to exchange anions in contrast to clay minerals [18]. The brucite-like layer can have varied chemistry; the most common $\mathrm{M}^{\mathrm{II}}$ cations are $\mathrm{Mg}$, $\mathrm{Zn}, \mathrm{Mn}, \mathrm{Co}$, and $\mathrm{Ni}$, and the $\mathrm{M}^{\mathrm{IIII}}$ cations are $\mathrm{Al}, \mathrm{Fe}$, and $\mathrm{Cr}$. In turn, the layer charge is most compensated by the following anions: $\mathrm{CO}_{3}{ }^{2-}, \mathrm{Cl}^{-}, \mathrm{NO}_{3}{ }^{-}$, and $\mathrm{SO}_{4}{ }^{2-}$. These anions control the interlayer distance, water content, and subsequently influence the adsorption properties. For applications, the LDH particles are most often synthesized using aqueous co-precipitation technique and thus it is possible to easily control their chemistry [19]. All these benefits allow for the adjustment of the LDH adsorbents for a specific target, in this case the FB1 mycotoxin.

Thus far, reports have been published on the adsorptive removal of FB1 by surfactant-treated minerals, e.g., clinoptilolite $[20,21]$. To the best of our knowledge, to date, research on the use of LDH for mycotoxins has not been published. Therefore, the objective of the presented study was to evaluate the adsorption properties of chemically different LDH materials in reaction with FB1 in model aqueous solutions. For the first time, this research investigates the mechanisms and factors which affect the removal efficiency by applying several analytical methods including X-ray diffraction, FTIR spectroscopy, and X-ray photoelectron spectroscopy.

\section{Experimental Methods}

\subsection{Materials}

The following chemicals of analytical grade were used for the LDH synthesis: $\mathrm{MgCl}_{2} \cdot 6 \mathrm{H}_{2} \mathrm{O}$, $\mathrm{Mg}\left(\mathrm{NO}_{3}\right)_{2} \cdot 6 \mathrm{H}_{2} \mathrm{O}, \mathrm{AlCl}_{3} \cdot 6 \mathrm{H}_{2} \mathrm{O}, \mathrm{AlNO}_{3} \cdot 9 \mathrm{H}_{2} \mathrm{O}, \mathrm{FeCl}_{3} \cdot 6 \mathrm{H}_{2} \mathrm{O}, \mathrm{Fe}\left(\mathrm{NO}_{3}\right)_{3} \cdot 9 \mathrm{H}_{2} \mathrm{O}$, and $\mathrm{NaOH}$. The chemicals were obtained from Avantor Company (Gliwice, Poland). For the adsorption experiments, a fumonisin $B_{1}$ from Fusarium moniliforme (FB1) was purchased from Sigma-Aldrich (CAS: 116355-83-0, $\geq 98 \%$ HPLC, St. Louis, MO, USA) (Figure 1). The following chemicals for FB1 quantification were 
obtained from Sigma-Aldrich: o-phthaldialdehyde, methanol, acetonitrile, disodium tetraborate, and 2-mercaptoethanol. Deionized water was used in all the experiments, unless stated otherwise.<smiles>CCCCC[C@H](C)[C@H](OC(=O)CC(CC(=O)O)C(=O)O)[C@@H](C[C@@H](C)C[C@H](O)CCCC[C@H](O)C[C@H](O)[C@H](C)N)OC(=O)CC(CC(=O)O)C(=O)O</smiles>

Figure 1. Structure of fumonisin $B_{1}$ molecule.

\subsection{Synthesis of $L D H$}

In total, $12 \mathrm{LDH}$ materials were prepared as listed in Table 1. The materials differed in the layer chemistry $(\mathrm{Mg} / \mathrm{Al}$ or $\mathrm{Mg} / \mathrm{Fe})$, metal ratio $\left(2: 1,3: 1,4: 1,6: 1\right.$ and 8:1), and type of interlayer anion $\left(\mathrm{Cl}^{-}\right.$ or $\mathrm{NO}_{3}$ ). The materials were synthesized by the standard co-precipitation method using aqueous metal salts. The solution containing both $\mathrm{M}(\mathrm{II})$ and $\mathrm{M}(\mathrm{III})$ in stoichiometric amounts was prepared with $100 \mathrm{~mL}$ of DI water. Regardless of the M(II) to M(III) ratio, the sum of the chemicals' mass was set at a constant. Thus, the solution density was also constant. This solution was slowly mixed with aqueous $5 \mathrm{M} \mathrm{NaOH}$ in a $2 \mathrm{~L}$ beaker which initially contained $400 \mathrm{~mL}$ of water at pH 10 . The precipitate formed in the $2 \mathrm{~L}$ beaker was constantly mixed with magnetic stirrer at room temperature. The whole synthesis lasted about 30-40 min. The portions of metal solution and base solution were gradually injected to maintain a constant $\mathrm{pH} 10$ throughout the synthesis. In the end, the formed precipitates were aged for $2 \mathrm{~h}$ at room temperature $\left(22^{\circ} \mathrm{C}\right)$ and were then washed with water and dried at $70^{\circ} \mathrm{C}$ for $24 \mathrm{~h}$. The materials with 6:1 and 8:1 metal ratios were not aged to prevent the formation of metal hydroxides (e.g., brucite) as indicated in our previous trials.

Table 1. The layered double hydroxide (LDH) materials used in the study with the chemistry of the brucite-like layer.

\begin{tabular}{lcccc}
\hline Chemistry & $\begin{array}{c}\text { M(II)/M(III) } \\
\text { Assumed Value }\end{array}$ & $\begin{array}{c}\text { M(II)/M(III) } \\
\text { Determined Value }\end{array}$ & $\begin{array}{c}\text { Interlayer } \\
\text { Anion }\end{array}$ & Symbol \\
\hline $\mathrm{Mg} / \mathrm{Al}$ & 2 & $1.94 \pm 0.07$ & $\mathrm{Cl}$ & $\mathrm{Mg}-\mathrm{Al}-\mathrm{Cl}-2$ \\
$\mathrm{Mg} / \mathrm{Al}$ & 3 & $2.76 \pm 0.07$ & $\mathrm{Cl}$ & $\mathrm{Mg}-\mathrm{Al}-\mathrm{Cl}-3$ \\
$\mathrm{Mg} / \mathrm{Al}$ & 4 & $3.24 \pm 0.08$ & $\mathrm{Cl}$ & $\mathrm{Mg}-\mathrm{Al}-\mathrm{Cl}-4$ \\
$\mathrm{Mg} / \mathrm{Al}$ & 6 & $4.51 \pm 0.04$ & $\mathrm{Cl}$ & $\mathrm{Mg}-\mathrm{Al}-\mathrm{Cl}-6$ \\
$\mathrm{Mg} / \mathrm{Al}$ & 8 & $5.26 \pm 0.04$ & $\mathrm{Cl}$ & $\mathrm{Mg}-\mathrm{Al}-\mathrm{Cl}-8$ \\
\hline $\mathrm{Mg} / \mathrm{Al}$ & 2 & $2.09 \pm 0.09$ & $\mathrm{NO}_{3}$ & $\mathrm{Mg}-\mathrm{Al}_{-} \mathrm{NO}_{3}-2$ \\
$\mathrm{Mg} / \mathrm{Al}$ & 3 & $2.97 \pm 0.06$ & $\mathrm{NO}_{3}$ & $\mathrm{Mg}-\mathrm{Al}-\mathrm{NO}_{3}-3$ \\
$\mathrm{Mg} / \mathrm{Al}$ & 4 & $3.56 \pm 0.06$ & $\mathrm{NO}_{3}$ & $\mathrm{Mg}-\mathrm{Al}-\mathrm{NO}_{3}-4$ \\
\hline $\mathrm{Mg} / \mathrm{Fe}$ & 2 & $1.72 \pm 0.01$ & $\mathrm{Cl}$ & $\mathrm{Mg}-\mathrm{Fe}-\mathrm{Cl}_{2}$ \\
$\mathrm{Mg} / \mathrm{Fe}$ & 3 & $2.48 \pm 0.01$ & $\mathrm{Cl}$ & $\mathrm{Mg}-\mathrm{Fe}-\mathrm{Cl}_{-3}$ \\
$\mathrm{Mg} / \mathrm{Fe}$ & 4 & $3.32 \pm 0.02$ & $\mathrm{Cl}$ & $\mathrm{Mg}-\mathrm{Fe}-\mathrm{Cl}_{-}$ \\
\hline $\mathrm{Mg} / \mathrm{Fe}$ & 2 & $1.88 \pm 0.01$ & $\mathrm{NO}_{3}$ & $\mathrm{Mg}-\mathrm{Fe}-\mathrm{NO}_{3}-2$ \\
$\mathrm{Mg} / \mathrm{Fe}$ & 3 & $2.58 \pm 0.02$ & $\mathrm{NO}_{3}$ & $\mathrm{Mg}-\mathrm{Fe}-\mathrm{NO}_{3}-3$ \\
$\mathrm{Mg} / \mathrm{Fe}$ & 4 & $3.53 \pm 0.03$ & $\mathrm{NO}_{3}$ & $\mathrm{Mg}-\mathrm{Fe}-\mathrm{NO}_{3}-4$ \\
\hline
\end{tabular}




\subsection{Adsorption Experiments}

The experiments were designed to investigate the adsorption efficiency and mechanisms in the reaction of FB1 with different LDH materials. All experiments were run in duplicates. The 200 ppm stock solution of FB1 was prepared in 1:1 acetonitrile/water solution. In all the experiments, LDH was introduced into the FB1 solution in the form of suspension. The LDH suspensions $(2 \mathrm{mg} / \mathrm{mL})$ were prepared by careful dispersion of the LDHs followed by sonification to ensure their homogeneity.

The first experiment performed for all materials tested the efficiency in reaction with $8 \mathrm{ppm}$ FB1 $\left(\mathrm{pH}_{\mathrm{in}}\right.$ 6.4). The LDH suspension containing $0.1 \mathrm{mg}$ of the material $(50 \mu \mathrm{L})$ was injected into $15 \mathrm{~mL}$ vials containing $5 \mathrm{~mL}$ of 8 ppm FB1 (suspension density: $20 \mathrm{mg} / \mathrm{L}$ ). The suspensions were shaken for $24 \mathrm{~h}$ to achieve equilibrium. The second experiment tested the adsorption efficiency for an FB1 concentration of 1.0-8.0 ppm. The rest of the experimental conditions remained as in the first experiment. This enabled us to obtain the adsorption isotherms for the selected LDH materials. In the third experiment, the $\mathrm{pH}$ effect was studied in the range of 2.2-11.2. The $8 \mathrm{ppm}$ FB1 solutions $(2.5 \mathrm{~mL})$ were diluted with $2.5 \mathrm{~mL}$ of an aqueous solution of $\mathrm{HCl}$ or $\mathrm{NaOH}$ in order to stabilize the $\mathrm{pH}$ to the required values. After the dilution, the starting FB1 concentration was equal to $4 \mathrm{ppm}$. The rest of the conditions remained as in the first experiment. The fourth and fifth experiments studied the effect of adsorbent dose and time on the removal efficiency, respectively. The following values of adsorbent dose were applied: 20, 40, 60, 80, 100, and $200 \mathrm{mg} / \mathrm{L}$. In turn, the kinetic experiment was run in the time range from 0.5 to $180 \mathrm{~min}$. In both experiments, the FB1 initial concentration was set to $4 \mathrm{ppm}$ with the rest of conditions remaining the same as in the first experiment.

In all cases, the samples for the analyses were filtered with $0.2 \mu \mathrm{m}$ syringe filters. The FB1 concentration was quantified using the Synergy HT Multi-Detection Microplate Reader (BioTek) equipped with a fluorescence detector. The excitation and emission wavelengths were set to $360 \mathrm{~nm}$ and $460 \mathrm{~nm}$, respectively. Each sample was analyzed at least 4 times to ensure high accuracy. Prior to the measurements, the $200 \mu \mathrm{L}$ aliquots of the analyzed samples were derivatized with $50 \mu \mathrm{L}$ of $o$-phthaldialdehyde (OPA) reagent directly in the dedicated black microplates. The whole process of OPA injection and measurements were carried out automatically to ensure repeatability of the results. The OPA reagent was prepared by dissolving $80 \mathrm{mg}$ of OPA in $2 \mathrm{~mL}$ of methanol and $10 \mathrm{~mL}$ of $0.1 \mathrm{M}$ disodium tetraborate. Then, $100 \mu \mathrm{L}$ of 2-mercaptoethanol was added and the solution was thoroughly mixed. The OPA reagent was prepared fresh before measurements and it was later stored in a vial wrapped with aluminum foil for no more than one week.

The reported adsorption capacity (A) was calculated by using the following formula:

$$
\mathrm{A}=\left(\mathrm{C}_{\mathrm{in}}-\mathrm{C}_{\mathrm{eq}}\right) \cdot \mathrm{V} / \mathrm{m}
$$

where $C_{\text {in }}$ and $C_{\mathrm{eq}}$ —initial and equilibrium concentration (mmol/L), respectively; V—solution volume $(\mathrm{L})$, and $\mathrm{m}$-adsorbent mass $(\mathrm{kg})$.

\subsection{Analytical Methods for Solid Samples}

The solid materials were characterized by X-ray diffraction (XRD), Fourier transformed infrared (FTIR) spectroscopy, scanning (SEM) and transmission (TEM) electron microscopy, X-ray photoelectron spectroscopy (XPS), and particle size analyzer (PSD). Moreover, the chemical composition of the brucite-like sheet was determined by the classical wet method. For that, the materials were dissolved in nitric acid and the $\mathrm{Mg}(\mathrm{II}), \mathrm{Al}(\mathrm{III})$, and $\mathrm{Fe}(\mathrm{III})$ concentrations were measured with an atomic absorption spectroscopy (AAS) - GBC SavanthAA spectrometer (Braeside, Australia). The XRD patterns were acquired on a Rigaku Miniflex 600 (Tokyo, Japan) and Bruker D8 Advance (Billerica, MA, USA) diffractometer with $\mathrm{CuK} \alpha(\lambda=1.5418 \AA)$ radiation. The patterns of powdered samples were recorded in the range of $2-72^{\circ} 2 \theta$ with a $0.05^{\circ} 2 \theta$ step. The infrared spectra were measured by $\mathrm{KBr}$ pellet technique (1 mg sample mixed with $200 \mathrm{mg} \mathrm{KBr)} \mathrm{with} \mathrm{a} \mathrm{Nicolet} 6700$ spectrometer (Thermo Scientific, Waltham, MA, USA). For each measurement, 64 scans were collected in the range of $4000-400 \mathrm{~cm}^{-1}$ with a $4 \mathrm{~cm}^{-1}$ 
resolution. The samples after FB1 adsorption experiments were recorded on a PerkinElmer Spectrum 100 spectrometer (Waltham, MA, USA) in transmission mode (range $4000-850 \mathrm{~cm}^{-1}$; resolution $4 \mathrm{~cm}^{-1}$ ). In this case, the samples' suspensions were dried on a $\mathrm{ZnS}$ disc and placed in a dedicated holder. The SEM images were obtained using FEI Quanta 600 FEG microscope (Hillsboro, OR, USA) under low vacuum. The powdered samples were prepared by placing powdered material on a carbon tape. The TEM images were collected using FEI Tecnai G2 F20 microscope at $200 \mathrm{keV}$. The samples were prepared by drying a drop of diluted LDH suspension on a lacey formvar/carbon TEM grid. The X-ray photoelectron spectroscopy (XPS) was used for the characterization of selected samples after reaction with FB1. The samples, prepared in the form of suspensions, were dried of glass disc directly used for the analysis. The spectra were recorded by the Omicron XPS/UPS system (Uppsala, Sweden) with an Argus detector equipped with dual Mg/Al X-ray source (Materials Characterization Facility, Texas A\&M University, College Station, TX, USA). The particle size distribution of the starting LDH materials was determined by a Beckman Coulter LS230 instrument (Brea, CA, USA) using diluted aqueous LDH suspensions.

\section{Results and Discussion}

\subsection{Characterization of Adsorbents}

\subsubsection{XRD Results and Chemistry of Brucite-Like Layers}

The recorded XRD patterns confirmed the formation of LDH materials in all cases (Figure 2). The diffractograms were typical of a LDH structure with the basal reflections found in the 7.8-8.7 $\AA$ range depending on the materials' chemistry [22]. The $\mathrm{d}_{003}$ values were also typical for LDH materials intercalated with chlorides, nitrates, and competitive carbonates from the air atmosphere. As shown in Table 1, the determined $\mathrm{M}(\mathrm{II}) / \mathrm{M}(\mathrm{III})$ ratio increased as expected. However, in some cases the values were lower than the expected values. In particular, this was observed for the samples with high $\mathrm{Mg}$ (II) contents. Nevertheless, the obtained materials had a clear difference in the $\mathrm{M}(\mathrm{II}) / \mathrm{M}(\mathrm{III})$ ratios and subsequently they significantly differed in their layer charge densities.

The peaks, due to other crystalline admixtures, were not observed, indicating the high purity of the LDH materials. The exception for that was the Mg-Al-Cl-8 sample where brucite was formed due to the high concentration of $\mathrm{Mg}(\mathrm{II})$ used in the synthesis (Figure 2a). For the $\mathrm{Mg}-\mathrm{Al}-\mathrm{Cl}$ samples, the basal spacing clearly increased with the increase of $\mathrm{Mg} / \mathrm{Al}$ ratios from 7.8 to $8.1 \AA$ (Figure 2a). This agreed with previous studies showing that the decrease of the layer charge leads to an increase of the interlayer spacing in the case of Cl-intercalated LDH materials [23]. This is due to a decrease in electrostatic attraction between positively charged layers and interlayer anions. In turn, for the $\mathrm{Mg}-\mathrm{Al}-\mathrm{NO}_{3}$ materials, the highest basal spacing value of $8.7 \AA$ was noticed for the $\mathrm{Mg}-\mathrm{Al}-\mathrm{NO}_{3}-2$ sample. For the $\mathrm{Mg}-\mathrm{Al}-\mathrm{NO}_{3}-3$ and $\mathrm{Mg}-\mathrm{Al}-\mathrm{NO}_{3}-4$ samples, the $\mathrm{d}$ value dropped to $8.1 \AA$. This agrees with earlier studies showing that nitrate orientation in contrast to chloride is significantly affected by the layer charge density [24,25]. Its vertical position is observed for high charge materials; thus, the $\mathrm{d}$ values are higher than for $\mathrm{LDH}$ structures with lower charge where $\mathrm{NO}_{3}$ adopts a horizontal arrangement. Moreover, for the $\mathrm{Mg}-\mathrm{Al}-\mathrm{NO}_{3}-2$ sample a dual nature of the $\mathrm{d}_{003}$ peak was observed which shows that part of the layers were intercalated by $\mathrm{NO}_{3}(8.7 \AA)$ and part by $\mathrm{CO}_{3}{ }^{2-}(7.7 \AA)$ (Figure 2c). The changes in $\mathrm{d}$ values for the $\mathrm{Mg}-\mathrm{Fe}-\mathrm{Cl}$ and $\mathrm{Mg}-\mathrm{Fe}-\mathrm{NO}_{3}$ materials were not observed despite the clear differences in the brucite-like layer chemistry that were noticed. The values in all cases were equal to $8.0 \AA$ (Figure $2 \mathrm{~b}, \mathrm{~d}$ ). 


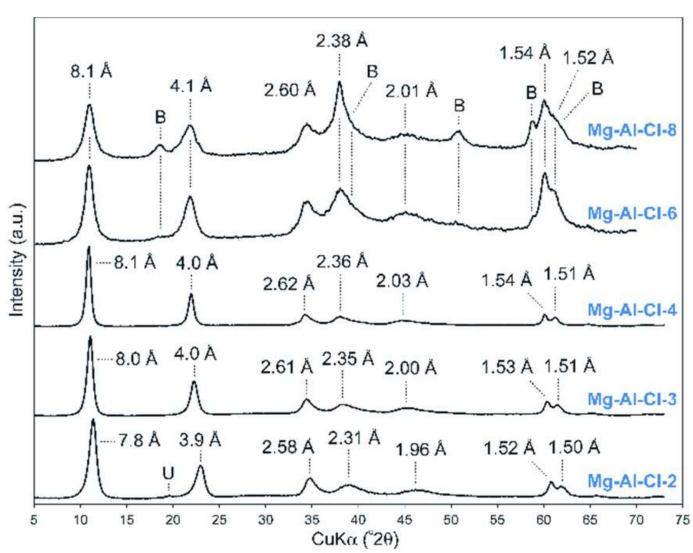

(a)

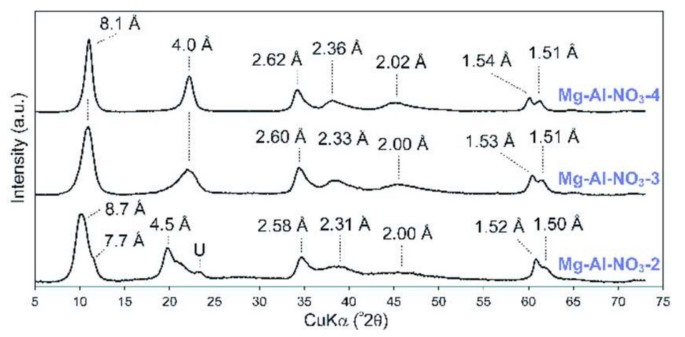

(c)

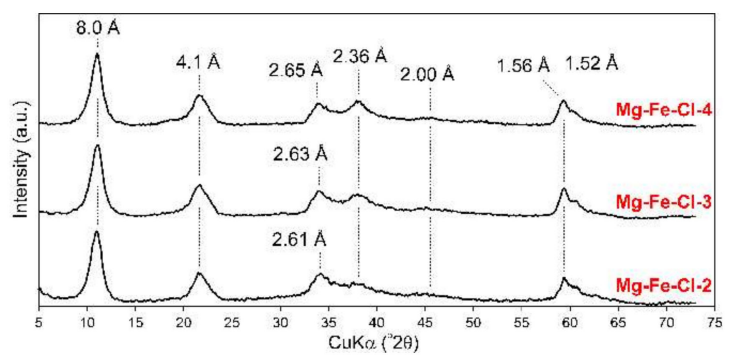

(b)

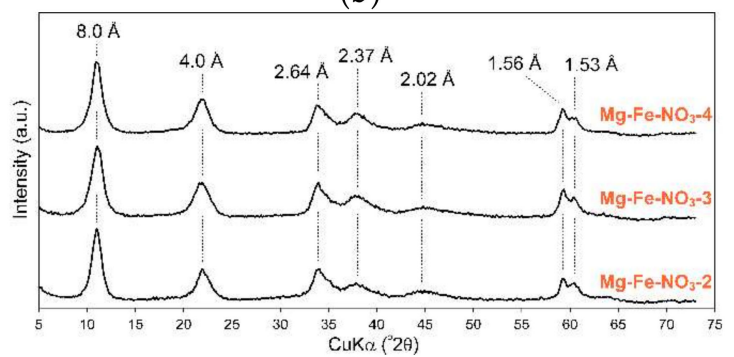

(d)

Figure 2. XRD patterns of raw LDH materials: (a) $\mathrm{Mg}-\mathrm{Al}-\mathrm{Cl}$, (b) $\mathrm{Mg}-\mathrm{Fe}-\mathrm{Cl}$, (c) $\mathrm{Mg}-\mathrm{Al}-\mathrm{NO}_{3}$, and (d) $\mathrm{Mg}-\mathrm{Fe}-\mathrm{NO}_{3}$, (B-brucite, U-unassigned).

\subsubsection{FTIR Results}

The FTIR spectra confirm and complement the data discussed in Section 3.1.1. The spectra are typical for hydrated LDH structure intercalated by chlorides or nitrates and accompanying carbonates. For the $\mathrm{Mg}-\mathrm{Al}-\mathrm{Cl}$ and $\mathrm{Mg}-\mathrm{Fe}-\mathrm{Cl}$ samples, the carbonate bands were found in the $1500-1350 \mathrm{~cm}^{-1}$ region (Figure 3a,b).

Two bands can be distinguished in this region: the $1374 \mathrm{~cm}^{-1}$ band attributed to monodentate carbonates and the $1483 \mathrm{~cm}^{-1}$ band attributed to bicarbonates [26]. It can be observed for the $\mathrm{Mg}-\mathrm{Al}-\mathrm{Cl}$ samples that the relative intensity of these bands visibly changes, indicating a greater proportion of bicarbonates with the decrease of layer charge. A similar trend was described in previous reports [19]. Such a trend was not evident for the $\mathrm{Mg}-\mathrm{Fe}-\mathrm{Cl}$ materials, where the intensity of the $1374 \mathrm{~cm}^{-1}$ and $1485 \mathrm{~cm}^{-1}$ bands remained similar despite chemistry differences. The presence of intercalated $\mathrm{NO}_{3}$ for the $\mathrm{Mg}-\mathrm{Al}-\mathrm{NO}_{3}$ and $\mathrm{Mg}-\mathrm{Fe}-\mathrm{NO}_{3}$ samples was evidenced by a sharp band at $1385 \mathrm{~cm}^{-1}$ attributed to $\mathrm{N}-\mathrm{O}$ stretching vibrations (Figure 3c,d) [24]. However, the presence of the accompanying bicarbonates still cannot be excluded as the characteristic band is visible at $1489 \mathrm{~cm}^{-1}$. The formation of brucite was confirmed for the $\mathrm{Mg}$-Al-Cl-8 sample rich in $\mathrm{Mg}$ (II) where a characteristic band at $3703 \mathrm{~cm}^{-1}$ was noticed (Figure 3a). A small content of brucite was also attested for the $\mathrm{Mg}-\mathrm{Fe}-\mathrm{Cl}$ and $\mathrm{Mg}-\mathrm{Fe}-\mathrm{NO}_{3}$ materials although this phase was not detected by XRD (Figure 3b,d). All the LDH samples contained water, thus a broad band in the $3800-3200 \mathrm{~cm}^{-1}$ region and a band at $\sim 1640 \mathrm{~cm}^{-1}$ were observed. The position of this band did not change with the change in layer chemistry for the Mg-Fe materials (Figure $3 b, d$ ). In turn, a visible shift of this broad band towards higher wavenumbers was noticed along with the increase in $\mathrm{Mg}$ (II) content and subsequent decrease of layer charge for the $\mathrm{Mg}$-Al materials (Figure 3a,b) [27]. A similar trend can be observed for the structural Me-O-Me bands which appear in the region below $800 \mathrm{~cm}^{-1}$. Regardless of the interlayer anions, for the $\mathrm{Mg}-\mathrm{Al}$ samples a shift of main structural band was noticed from 672 to $581 \mathrm{~cm}^{-1}$ (Mg-Al-Cl samples) and from 671 to $594 \mathrm{~cm}^{-1}$ $\left(\mathrm{Mg}-\mathrm{Al}-\mathrm{NO}_{3}\right)$. 


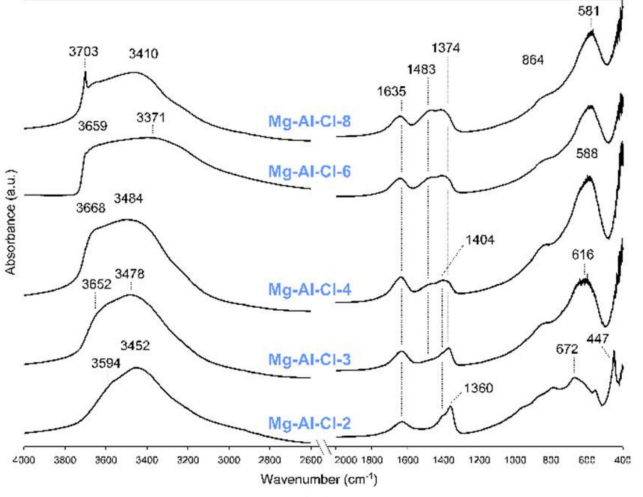

(a)

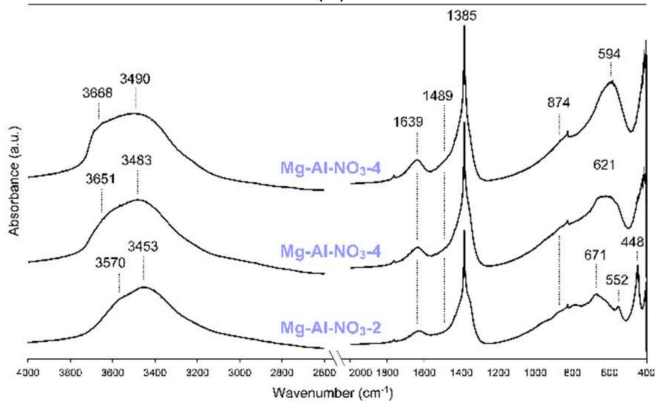

(c)

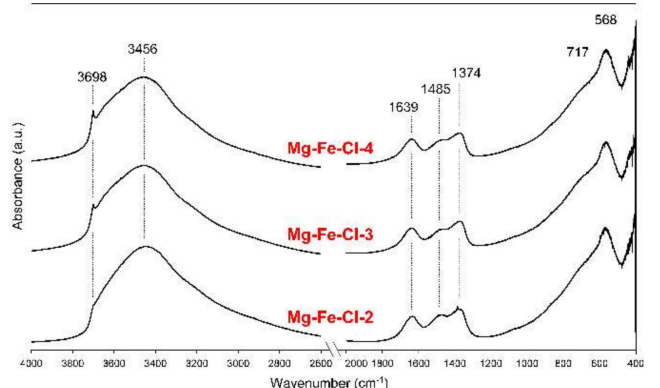

(b)

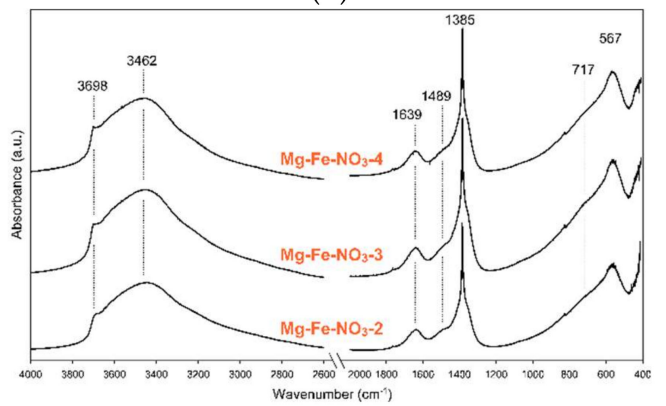

(d)

Figure 3. FTIR spectra of raw LDH materials: (a) $\mathrm{Mg}-\mathrm{Al}-\mathrm{Cl}$, (b) $\mathrm{Mg}-\mathrm{Fe}-\mathrm{Cl}$, (c) $\mathrm{Mg}-\mathrm{Al}-\mathrm{NO}_{3}$ and (d) $\mathrm{Mg}-\mathrm{Fe}-\mathrm{NO}_{3}$.

\subsubsection{SEM/TEM Results}

The microscopic observations did not reveal significant differences between $\mathrm{Mg}-\mathrm{Al}$ and $\mathrm{Mg}-\mathrm{Fe}$ samples. Regardless of the brucite-layer chemistry and the type of interlayer anion, the differences were hardly visible. Thus, the images of two representative $\mathrm{Mg}-\mathrm{Al}-\mathrm{Cl}-2$ and $\mathrm{Mg}-\mathrm{Fe}-\mathrm{Cl}-2$ samples were included. The SEM images showed aggregates of typical layered particles which started to be noticeable under magnification of 40,000-50,000× (Figure 4a,d). The sheet-like particles formed characteristic "house of cards" structures resulting from face to edge interaction. A TEM inspection enabled us to observe individual rounded particles with diameters in the range of $\sim 20-200 \mathrm{~nm}$ and thickness in the range from $\sim 10-20 \mathrm{~nm}$. The observations at high magnification of $\sim 400,000 \times$ showed nanometer-sized individual layers of the LDH particles (Figure 4c). The microscopic data agreed with particle size measurements (Figure S1) where two dominating populations of particles can be distinguished: (1) $<250 \mathrm{~nm}$-individual particles, and (2) $1.0-2.5 \mu \mathrm{m}$-aggregates of particles forming clusters.

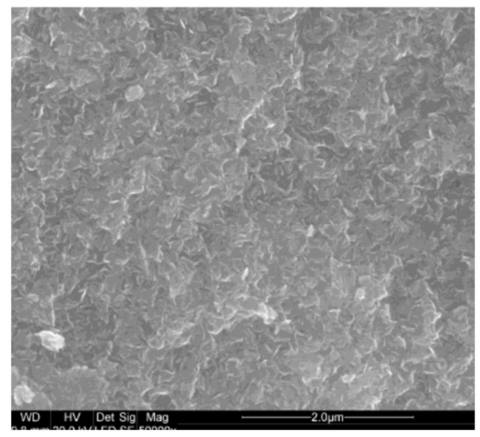

(a)

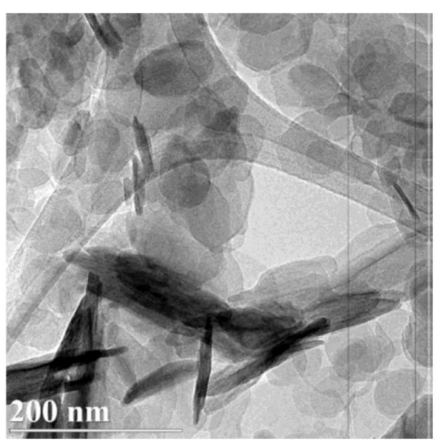

(b)

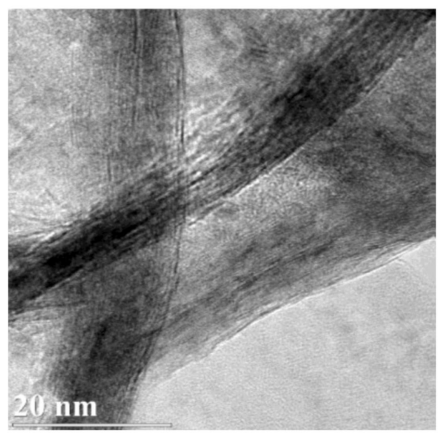

(c)

Figure 4. Cont. 


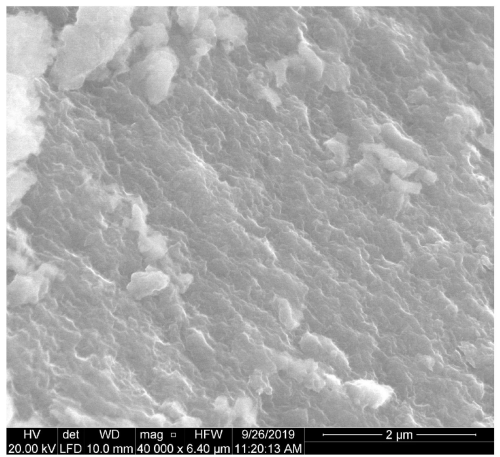

(d)

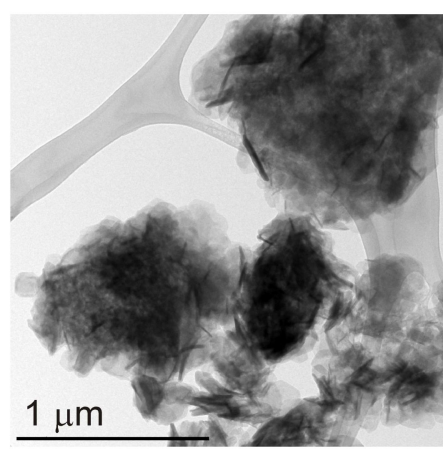

(e)

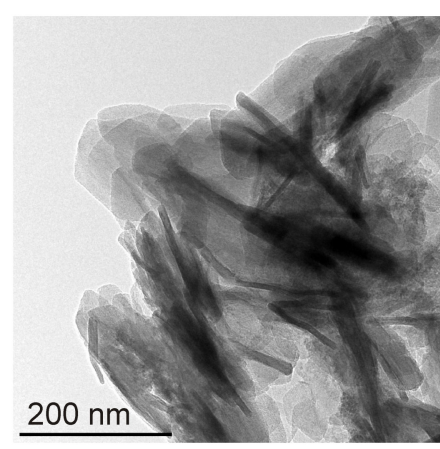

(f)

Figure 4. SEM and TEM images of LDH materials: (a-c) Mg-Al-Cl-2 and (d-f) Mg-Fe-Cl-2.

\subsection{Adsorption Experiments}

The initial test evaluating the LDH removal efficiency of FB1 was performed in identical conditions for all materials with the exception of Mg-Al-Cl-6 and Mg-Al-Cl-8 (Figure 5). In this experiment, the mass of introduced FB1 in relation to adsorbent mass was kept equal to $40 \%$. This enabled the direct comparison of the adsorption capacity between all the materials. The results clearly show two groups of materials with different adsorption behaviors. The first group of $\mathrm{Mg}$-Al materials intercalated either with $\mathrm{Cl}$ or $\mathrm{NO}_{3}$, which had a higher adsorption capacity for FB1. For this group, a trend of increasing FB1 adsorption capacity along with layer charge decrease could be noticed. The second group consisted of Mg-Fe materials with lower FB1 adsorption capacity, especially in the case of $\mathrm{Mg}-\mathrm{Fe}-\mathrm{NO}_{3}$ materials. For the $\mathrm{Mg}$-Fe sample, the trend between adsorption capacity and layer charge was not evident. The $\mathrm{pH}_{\mathrm{in}}$ of 6.37 did not change substantially after the experiments although visibly higher values were noticed for the $\mathrm{Mg}-\mathrm{Fe}$ samples as compared to $\mathrm{Mg}-\mathrm{Al}$ samples. The calculated average values of adsorption capacity (in $\mathrm{mmol} / \mathrm{kg}$ ) were as follows: $\mathrm{Mg}-\mathrm{Al}-\mathrm{Cl}-2$ : $0.083 \pm$ 0.02, Mg-Al-Cl-3: $0.125 \pm 0.027, \mathrm{Mg}-\mathrm{Al}-\mathrm{Cl}-4: 0.134 \pm 0.015, \mathrm{Mg}-\mathrm{Fe}-\mathrm{Cl}-2: 0.072 \pm 0.014$, Mg-Fe-Cl-3: $0.080 \pm$ 0.015, Mg-Fe-Cl-4: $0.068 \pm$ 0.018, Mg-Al-NO $-2: 0.077 \pm 0.015, \mathrm{Mg}-\mathrm{Al}_{3}-\mathrm{NO}_{3}-3$ : $0.093 \pm 0.019, \mathrm{Mg}-\mathrm{Al}-\mathrm{NO}_{3}-4: 0.119 \pm$ 0.017, $\mathrm{Mg}-\mathrm{Fe}-\mathrm{NO}_{3}-2: 0.046 \pm 0.016, \mathrm{Mg}-\mathrm{Fe}-\mathrm{NO}_{3}-3: 0.045 \pm 0.016$, and $\mathrm{Mg}-\mathrm{Fe}-\mathrm{NO}_{3}-4: 0.066 \pm 0.016$. It is worth noting that the corresponding average FB1 content (presented in Figure 5) was in the range of $\sim 3.0-10.0 \mathrm{wt}$ \% with the highest values calculated for the Mg-Al samples.

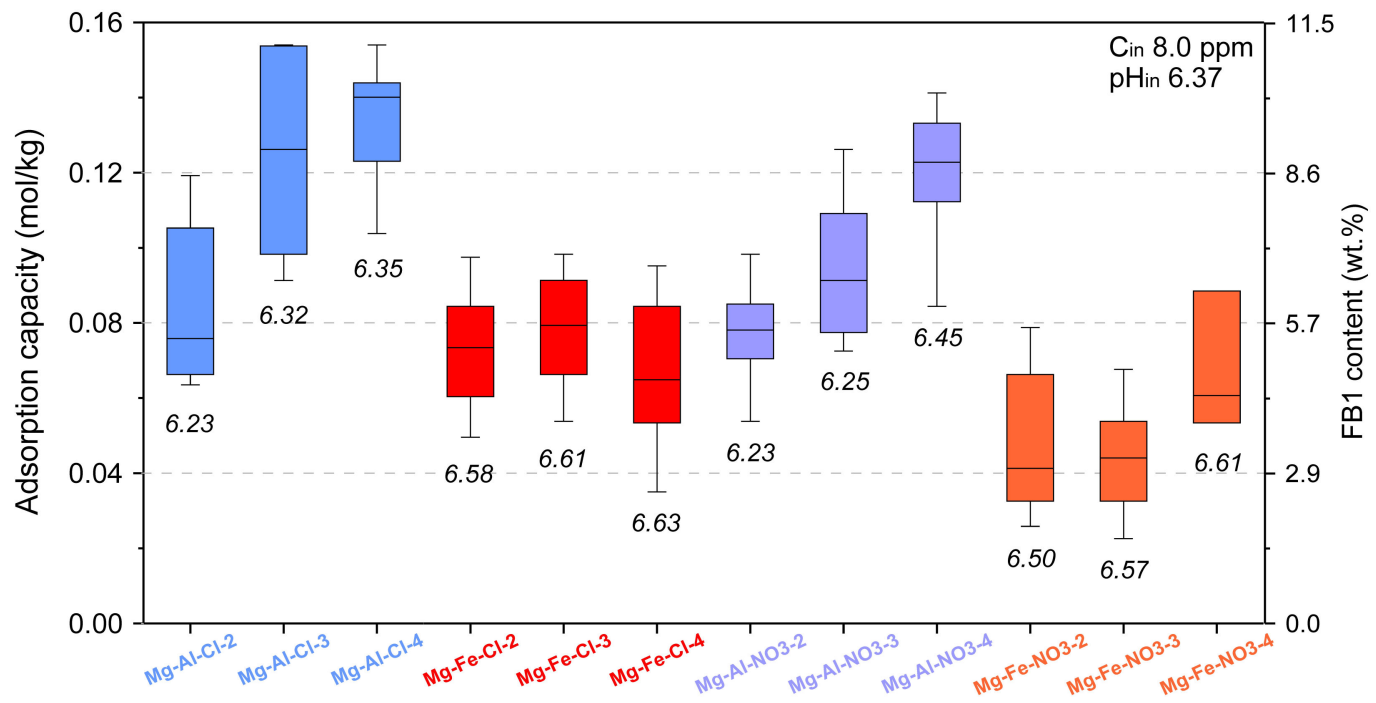

Figure 5. Adsorption capacity of LDH materials tested for 8 ppm FB1. 
To confirm the trends observed in Figure 5 for the selected materials, full adsorption isotherms were determined in a broad FB1 concentration range (Figure 6). In agreement with the initial observations, the $\mathrm{Mg}$-Fe materials showed visibly lower adsorption capacity: $\mathrm{Mg}-\mathrm{Fe}-\mathrm{Cl}-2: 0.047 \pm 0.009 \mathrm{mmol} / \mathrm{kg}$ and $\mathrm{Mg}-\mathrm{Fe}-\mathrm{NO}_{3}-2: 0.047 \pm 0.007 \mathrm{mmol} / \mathrm{kg}$. Thus, these materials were excluded from further investigations. The full isotherms confirmed a trend of increasing adsorption capacity along with decreasing layer charge density for the following groups of materials: Mg-Al-Cl- $<\mathrm{Mg}-\mathrm{Al}-\mathrm{Cl}-3<\mathrm{Mg}-\mathrm{Al}-\mathrm{Cl}-4<$ $\mathrm{Mg}-\mathrm{Al}-\mathrm{Cl}-6$ (Figure 6a) and Mg-Al-NO $\mathrm{N}_{3}-2<\mathrm{Mg}-\mathrm{Al}-\mathrm{NO}_{3}-3<\mathrm{Mg}-\mathrm{Al}-\mathrm{NO}_{3}-4$ (Figure 6b). In particular, the adsorption capacity of Mg-Al-Cl-6 sample with the lowest layer charge density had the greatest adsorption capacity of $0.153 \pm 0.02 \mathrm{mmol} / \mathrm{kg}$. Likely due to the high content of brucite as detected by XRD and FTIR in the Mg-Al-Cl-8 sample, its FB1 adsorption capacity was lower and did not follow the trend.

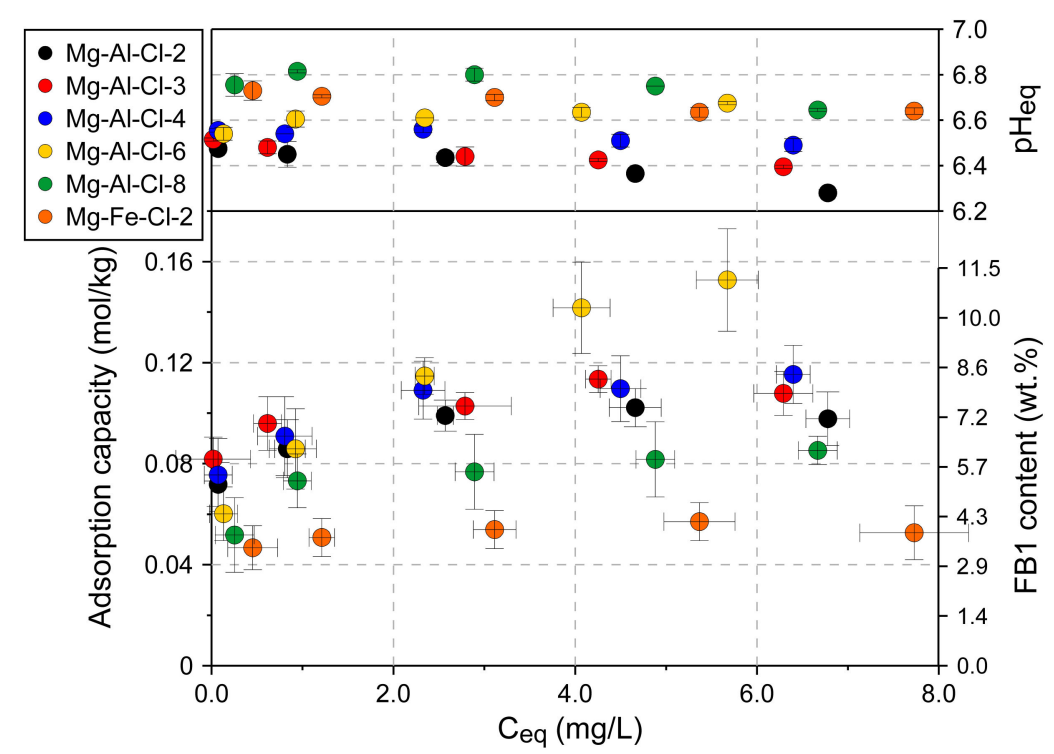

(a)

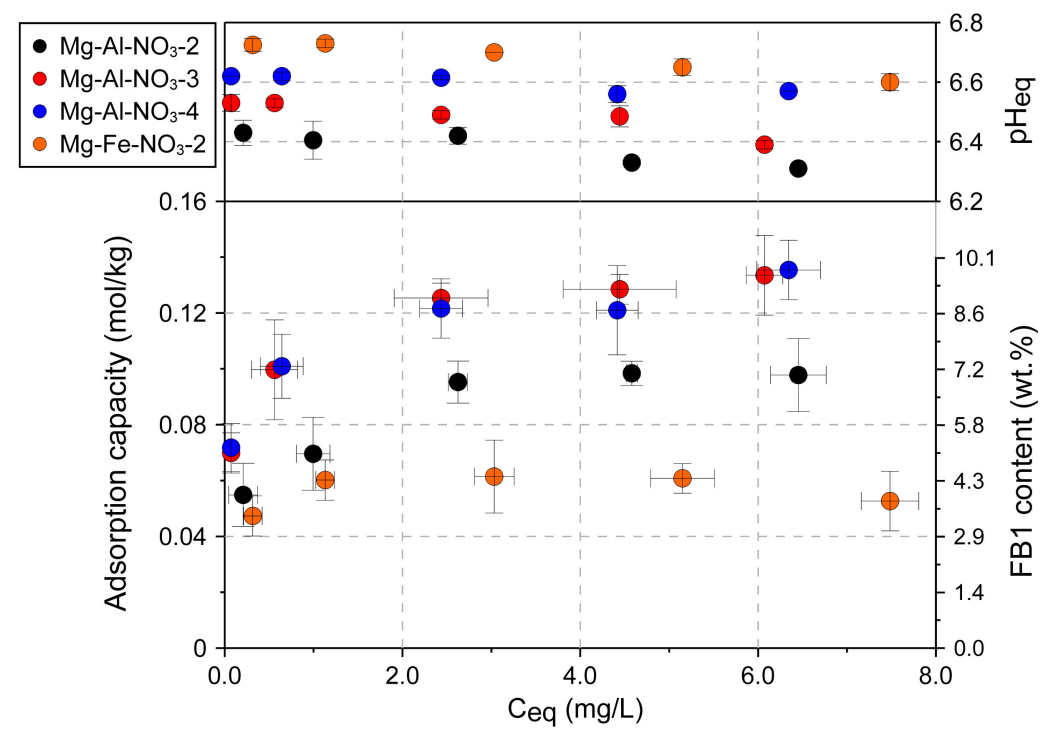

(b)

Figure 6. Adsorption isotherms for $\mathrm{LDH}$ materials: (a) $\mathrm{Cl}$ intercalated samples and (b) $\mathrm{NO}_{3}$ intercalated samples. 
The $\mathrm{pH}$ effect was investigated for 4 selected materials: $\mathrm{Mg}-\mathrm{Al}-\mathrm{Cl}-2, \mathrm{Mg}-\mathrm{Al}-\mathrm{Cl}-4, \mathrm{Mg}-\mathrm{Al}-\mathrm{NO}_{3}-2$, and $\mathrm{Mg}-\mathrm{Al}-\mathrm{NO}_{3}-4$ (Figure 7). The results showed a significant impact of $\mathrm{pH}$ on the adsorption capacity. In general, similar trends for all the materials were observed with the FB1 greatest removal efficiency in the range of $\mathrm{pH}$ equilibrium equal to $4-5$. In this range, the adsorption capacity reached $0.219 \pm 0.01$ $\mathrm{mmol} / \mathrm{kg}$ which corresponds to $15.8 \pm 0.75 \mathrm{wt} . \%$ of FB1 (Mg-Al-Cl-4 sample). The FB1 uptake was slightly lower in extreme acidic $(\mathrm{pH}<3)$ or basic $(\mathrm{pH}>11)$ conditions as compared to neutral $\mathrm{pH}$ values in the range of $6-8$.

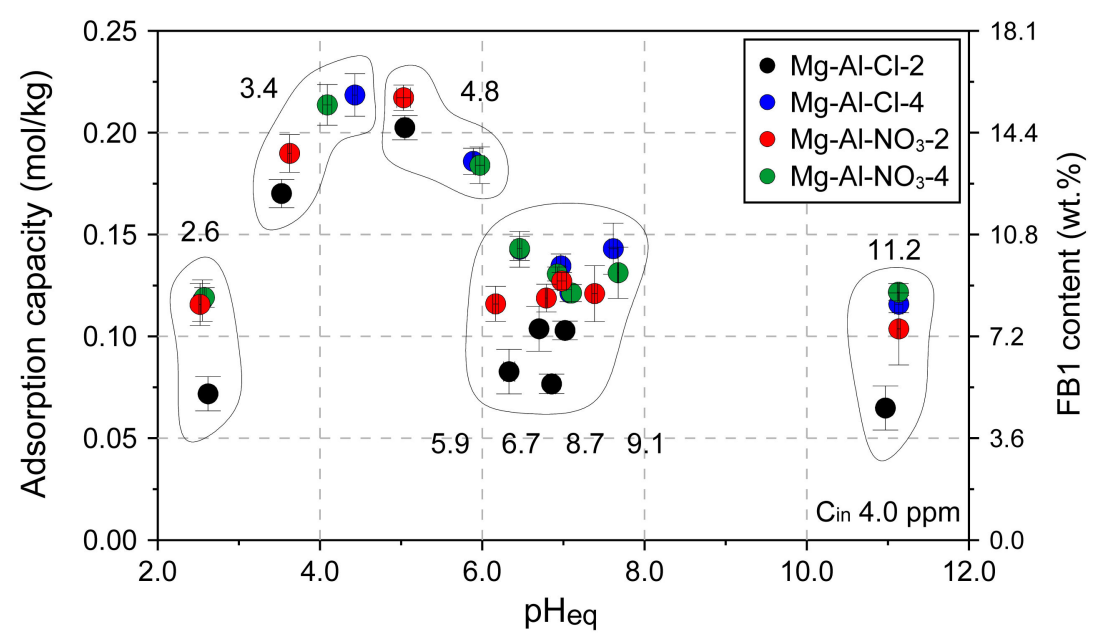

Figure 7. The $\mathrm{pH}$ effect on adsorption capacity of selected LDH materials. The values on the graph indicate initial $\mathrm{pH}$ values.

The effect of adsorbent dose on adsorption capacity was tested for the $\mathrm{Mg}-\mathrm{Al}-\mathrm{Cl}-4$ and $\mathrm{Mg}-\mathrm{Al}-\mathrm{NO}_{3}-4$ samples (Figure 8). The experiment confirmed the remarkable adsorption properties of LDH towards FB1. The FB1 was removed in $\sim 95 \%$ when the amount of introduced LDH was only $200 \mathrm{mg} / \mathrm{L}$. The adsorption itself was a fast process with most of FB1 removed in the first minute of interaction, as shown for the $\mathrm{Mg}-\mathrm{Al}-\mathrm{Cl}-2$ sample (Figure 9).

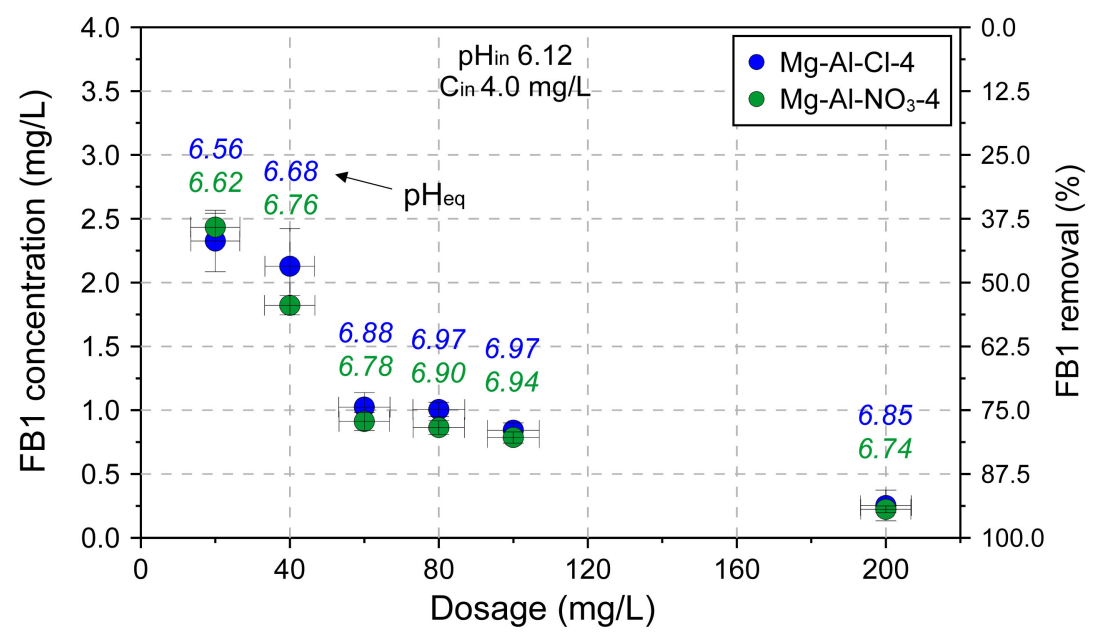

Figure 8. The dosage effect on adsorption capacity of selected LDH materials.

It is worth underlining that the obtained values of adsorption capacity were much greater than the values reported thus far. For example, a zeolitic material modified with octadecyldimethylbenzylammonium surfactant reached an adsorption capacity corresponding to $0.0149 \mathrm{~mol} / \mathrm{kg}(10.819 \mathrm{mg} / \mathrm{g})$ at $\mathrm{pH} 3$ [21]. Surfactant-modified minerals were able to reduce FB1 concentration in acidic conditions with a visible decrease in removal efficiency with $\mathrm{pH}$ increase [20]. 
The other disadvantage of these materials is the much higher amount of adsorbent necessary for the reaction $0.4-10 \mathrm{~g} / \mathrm{L}$. The FB1 uptake was highly dependent on the surface coverage of the surfactant which determined the type of interactions changing from $\mathrm{pH}$-dependent to hydrophobic pH-independent attraction [20].

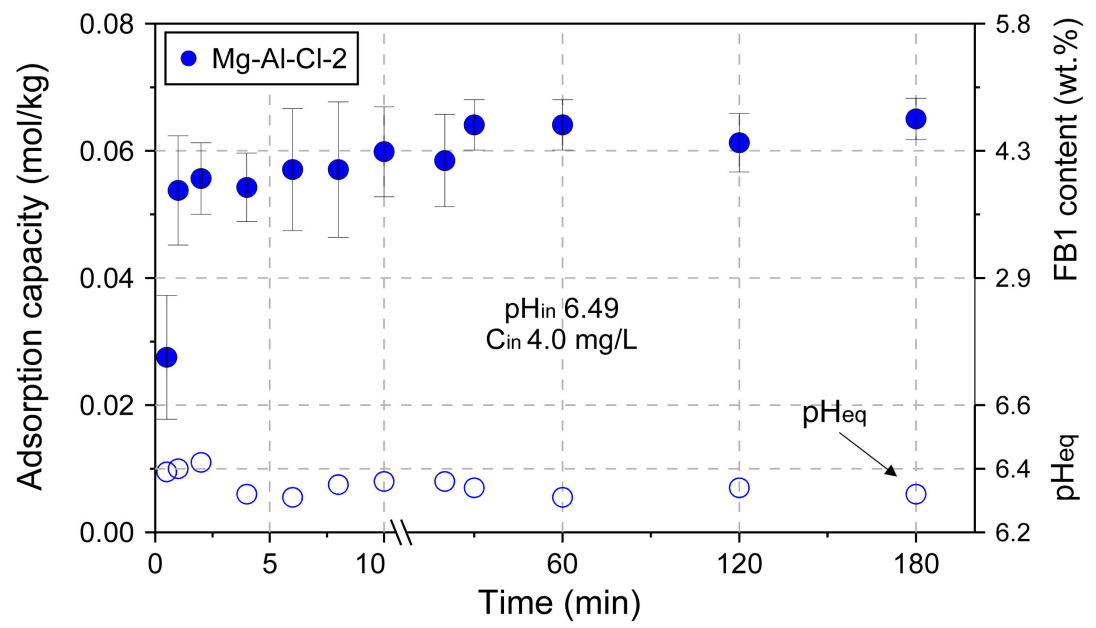

Figure 9. The adsorption kinetics examined for the $\mathrm{Mg}-\mathrm{Al}-\mathrm{Cl}-2$ sample.

\subsection{Insight into Removal Mechanisms}

\subsubsection{XRD and FTIR Analysis}

The experimental results suggested that the interaction of FB1 molecule with LDH structure was complex and mainly influenced by the $\mathrm{pH}$ of the solution. This relates to the structure of FB1 having four distinct carboxyl groups which can undergo protonation/deprotonation and its possible conformational changes [28,29]. On the other side the LDH adsorbent structure shows different changes in stability due to $\mathrm{pH}$, with partial dissolution occurring below $\mathrm{pH} 3$ and high stability in basic conditions ( $\mathrm{pH} 8-10)$ [30].

Moreover, in the case of adsorbents having a layered structure, two main possibilities exist in terms of the location of adsorbate molecules. The first one is the migration of molecules into the interlayer space leading to intercalation. The second one is the surface adsorption of molecules. The research we performed showed that the intercalation did not take place in any of the applied conditions even at a very high concentration of FB1 equal to 100 or 200 ppm (Figure 10). The XRD results clearly showed that the initial basal spacing peak was not shifted and was still present at $7.8 \AA$ (Mg-Al-Cl-2 sample) or $8.1 \AA$ (Mg-Al-Cl-6 sample) (Figure 10).

The protonation/deprotonation behavior of pure FB1 was followed with ATR-FTIR by analyzing its 20 ppm aqueous solution in the range from 2.6-11.0 (Figure 11a). In the FB1 spectrum, the following regions can be distinguished and assigned to molecular vibrations: $3500-3100 \mathrm{~cm}^{-1}$ : N-H and $\mathrm{H}_{2} \mathrm{O}$ stretching, 3100-2700 cm ${ }^{-1}$ : C-H stretching, 1770-1680 cm ${ }^{-1}: \mathrm{C}=\mathrm{O}$ stretching, 1680-1600 cm ${ }^{-1}$ : $\mathrm{H}_{2} \mathrm{O}$ bending, $1680-1490 \mathrm{~cm}^{-1}: \mathrm{COO}^{-}$as stretching, and $1490-1280 \mathrm{~cm}^{-1}: \mathrm{COO}^{-}$sym stretching. The most visible changes upon $\mathrm{pH}$ increase are visible in the regions assigned to $\mathrm{COO}^{-}$groups where bands with maxima at $\sim 1570 \mathrm{~cm}^{-1}$ and $1410 \mathrm{~cm}^{-1}$ appear (Figure 11a). This confirms deprotonation phenomena of FB1 which is clear at $\mathrm{pH}_{\mathrm{eq}}$ 6.4. However, it should be underlined that according to computer modeling, the FB1 molecule can be negatively charged already at $\mathrm{pH} 4$ as it undergoes gradual deprotonation, e.g., in EDTA and BTCA compounds [31]. These types of molecules have few pKa values corresponding to several carboxyl groups. The $\mathrm{pH}$ effect on the FB1 structure is also visible in the $\mathrm{N}-\mathrm{H}$ stretching region where at high $\mathrm{pH}$ a more symmetric band with maximum at $3300 \mathrm{~cm}^{-1}$ can be observed and assigned to free $\mathrm{NH}_{2}$. In turn, in acidic conditions where the protonation of $\mathrm{NH}_{2}$ occurs the bands in this region become broad with maxima at 3450 and $3150 \mathrm{~cm}^{-1}$. The $\mathrm{C}-\mathrm{H}$ stretching bands were only 
slightly affected by the $\mathrm{pH}$ and these changes may be connected with the conformational changes of FB1. Previous molecular modeling studies conducted in vacuo showed that the backbone carbon chain may fold to a certain degree and FB1 creates a cage-like structure [29,32]. However, later investigations on FB1 behavior in aqueous solutions proved that stable folded conformation are unlikely due to the shielding properties of water molecules [28]. Thus, most probably the FB1 exists in a relatively extended structural state in an aqueous solution.

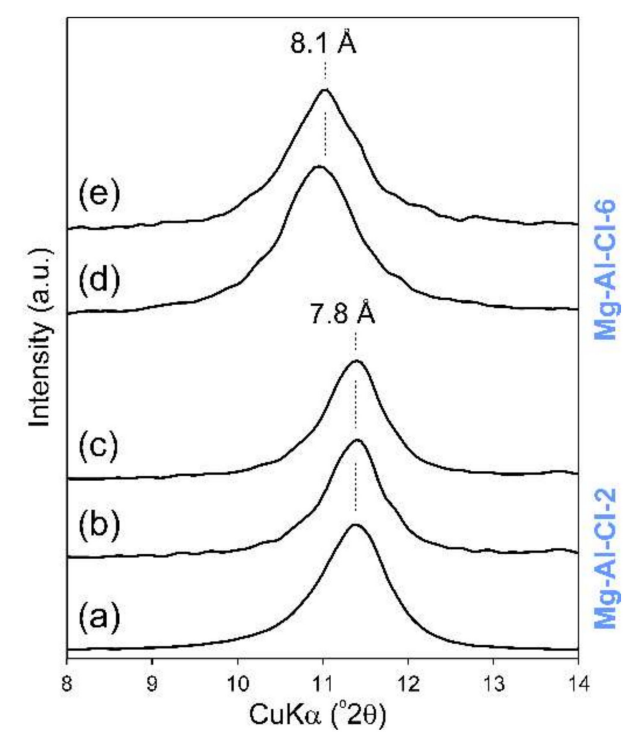

Figure 10. XRD patterns of selected LDH samples after reaction with FB1: (a) raw $\mathrm{Mg}-\mathrm{Al}-\mathrm{Cl}-2$ sample, (b) FB1-treated Mg-Al-Cl-2 sample (pH 5, $\mathrm{C}_{\mathrm{FB} 1} 100$ ppm), (c) FB1-treated Mg-Al-Cl-2 sample (pH 7, $\mathrm{C}_{\mathrm{FB} 1} 100$ ppm), (d) raw Mg-Al-Cl-6 sample, and (e) FB1-treated Mg-Al-Cl-6 sample (pH 5, $\left.\mathrm{C}_{\mathrm{FB} 1} 200 \mathrm{ppm}\right)$.

In order to investigate the changes of FB1 removal efficiency versus $\mathrm{pH}$, the $\mathrm{Mg}-\mathrm{Al}-\mathrm{Cl}-2$ sample was reacted with FB1 and afterwards the FTIR spectra were recorded (Figure 11b). As reported in earlier studies in acidic conditions, the LDH structure becomes unstable and partial dissolution occurs leading to the release of metals belonging to the brucite-like layer [30]. The LDH dissolution was found to reach $\sim 30 \mathrm{wt} . \%$ after $24 \mathrm{~h}$ of reaction. The FTIR spectrum recorded for $\mathrm{pH}_{\mathrm{eq}} 2.6$ proves a partial LDH dissolution with the clear removal of intercalated $\mathrm{CO}_{3}{ }^{2-}$ due to lack of band present at $\sim 1350 \mathrm{~cm}^{-1}$. Therefore, LDH structural instability was responsible for the slightly lower FB1 removal in acidic conditions. On the other hand, in basic conditions ( $\mathrm{pH}_{\mathrm{eq}} 10.9$ ), where $\mathrm{LDH}$ is stable, the removal efficiency was affected by the competitive adsorption of hydroxide ions. Such an effect is known to drastically reduce the uptake of anionic forms in aqueous solutions [33]. Therefore, although the FB1 was totally deprotonated in these conditions the uptake was not as efficient as it was for neutral $\mathrm{pH}$ values.

The differences in adsorption behavior between $\mathrm{pH} 5$ and 7 may be explained by the analysis of FTIR spectra recorded at $\mathrm{pH}_{\mathrm{eq}} 5.1$ and 7.3 (Figure 11b). The most important difference is the lack of $\mathrm{CO}_{3}{ }^{2-}$ band at $\sim 1350 \mathrm{~cm}^{-1}$ for $\mathrm{pH}_{\mathrm{eq}} 5.1$ indicating that monodentate carbonates were deintercalated and/or decomposed on LDH surface in this condition. The presence of carbonates is known to hinder the adsorption of anions which is also confirmed in the case of FB1 adsorption. The synthesis of carbonate-free LDHs is possible by, e.g., using inert gas atmosphere and/or decarbonated water. However, due to their high affinity to $\mathrm{CO}_{2}$, their use as adsorbents of anions always leads to competitive effects with $\mathrm{CO}_{3}{ }^{2-}$ formed in the reaction of $\mathrm{CO}_{2}$ with $\mathrm{H}_{2} \mathrm{O}$. This competitive effect subsequently depends on the type of carbonates present in the interlayer which can form monodentate and bidentate coordination and exist as bicarbonates [16,34]. 
The higher FB1 removal efficiency by low charge LDHs may be connected to the lower number of carbonates and the simultaneous increase of non-polar sites and thus the matching between adsorption domains of LDH with FB1 structure becomes possible. A similar mechanism was reported for high charge smectites in reaction with aflatoxin molecules [6]. The authors suggested that smectite adsorption properties in this case may be improved by charge reduction.

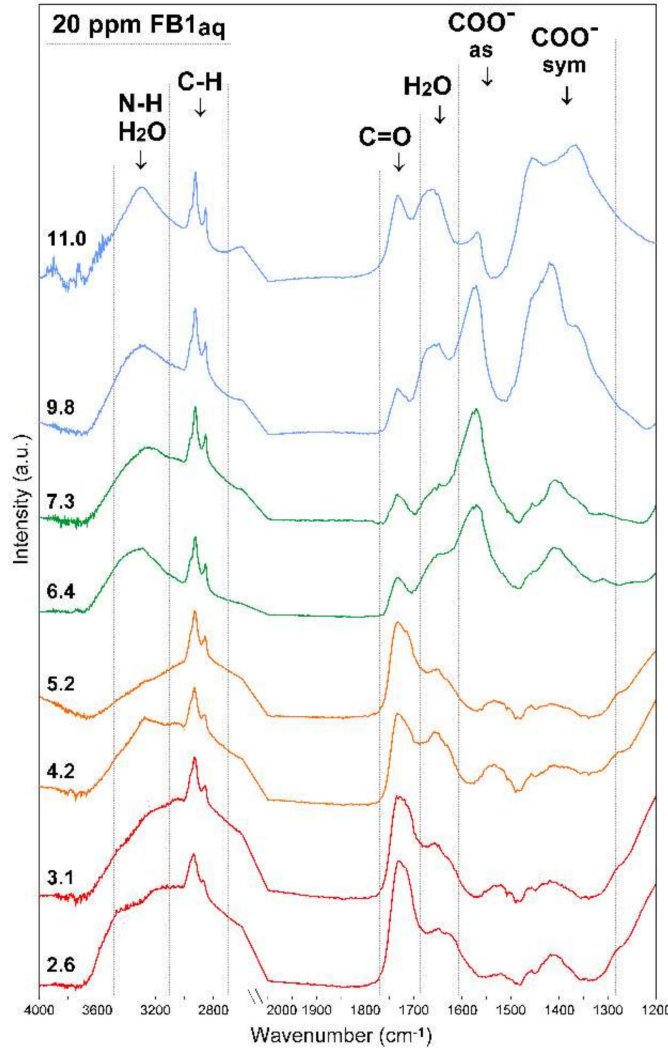

(a)

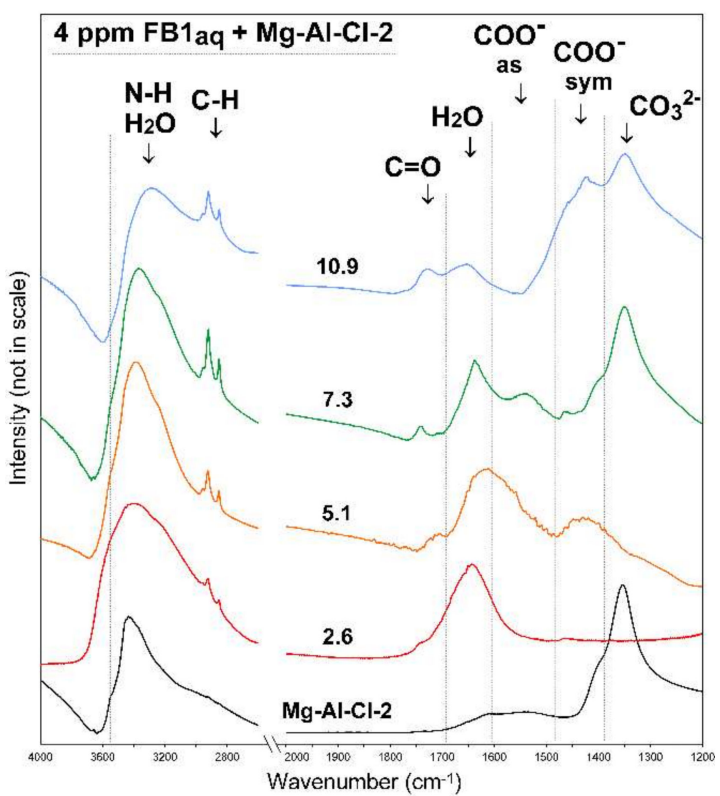

(b)

Figure 11. FTIR spectra of: (a) FB1 versus $\mathrm{pH}\left(\mathrm{C}_{\mathrm{FB} 1} 20 \mathrm{ppm}\right)$ and (b) FB1-treated Mg-Al-Cl-2 sample versus $\mathrm{pH}\left(\mathrm{C}_{\mathrm{FB} 1} 4 \mathrm{ppm}\right)$. The values on the graphs indicate equilibrium $\mathrm{pH}$.

\subsubsection{XPS Analysis}

To further investigate the interaction of FB1 with LDH materials, XPS analysis was used to obtain insight into possible changes in the elements' local environment. The $\mathrm{Mg}-\mathrm{Al}-\mathrm{Cl}-2$ was selected and Mg2p, Al2p, and O1s spectra were recorded before and after reaction with FB1 at pH 5 and 7 (Figure 12). For the Mg2p spectra, the band with maximum in the range of 49.3-49.8 ppm can be attributed to $\mathrm{Mg}(\mathrm{OH})_{2}$ typical for $\mathrm{LDH}$ structures (Figure 12a,d,g) [35]. In turn, the maxima of bands corresponding to $\mathrm{Al}(\mathrm{OH})_{3}$ building the brucite-like layer are visible in the range of 73.4-73.7 ppm in the Al2p spectra [36]. The O1s spectra show two main components connected to oxygen bonded with $\mathrm{Mg}$ (530.4-530.9 ppm) and $\mathrm{Al}$ (532.1-532.5 ppm) [36].

Clear changes were visible in the bands' positions and shapes in the Mg2p, Al2p, and O1s spectra of FB1-treated sample at pH 5 where the adsorption was the most efficient (Figure 12j-1). In particular, the Mg2p spectrum was most affected where the main band was shifted from 49.8 to $50.3 \mathrm{ppm}$ and a new visible component at $50.6 \mathrm{ppm}$ was visible (Figure 12j). This component can be assigned to carboxylate moieties $\mathrm{COO}^{-}$which interact with $\mathrm{LDH} \mathrm{Mg}$ sites. This agrees with previous reports showing the binding energy of $\mathrm{Mg}$ acetate equal to $50.55 \mathrm{ppm}$ in the $\mathrm{Mg} 2 \mathrm{p}$ spectra and suggests the electrostatic interaction of FB1 with LDH positively charged sites [37]. This band is less pronounced in the $\mathrm{Mg} 2 \mathrm{p}$ spectrum of FB1-treated $\mathrm{Mg}$-Al-Cl-2 sample at $\mathrm{pH} 7$ where the carbonate competition was greater and hindered FB1 adsorption (Figure 12d). This band was not present in the Mg2p spectra of 
Mg-Al-Cl-2 recorded after equilibration at $\mathrm{pH} 5$ and 7 (Figure 12a,g). The FB1 interaction with Mg sites had a clear impact on the O1s spectra where the main band position was shifted to higher binding energy of $531.8 \mathrm{ppm}$ and the component at $532.5 \mathrm{ppm}$ appeared (Figure 121). This also confirms the presence of $\mathrm{COO}^{-}$moieties interacting with the LDH surface, in agreement with earlier studies [36,37]. Because the adsorption of FB1 takes place on the brucite-like layers, it results in structural distortions of the metal octahedra and thus the local environment of $\mathrm{Al}$ was is altered, as evidenced by the splitting and broadening of bands in the Al2p spectra. However, these changes were not as significant as they were for the Mg.
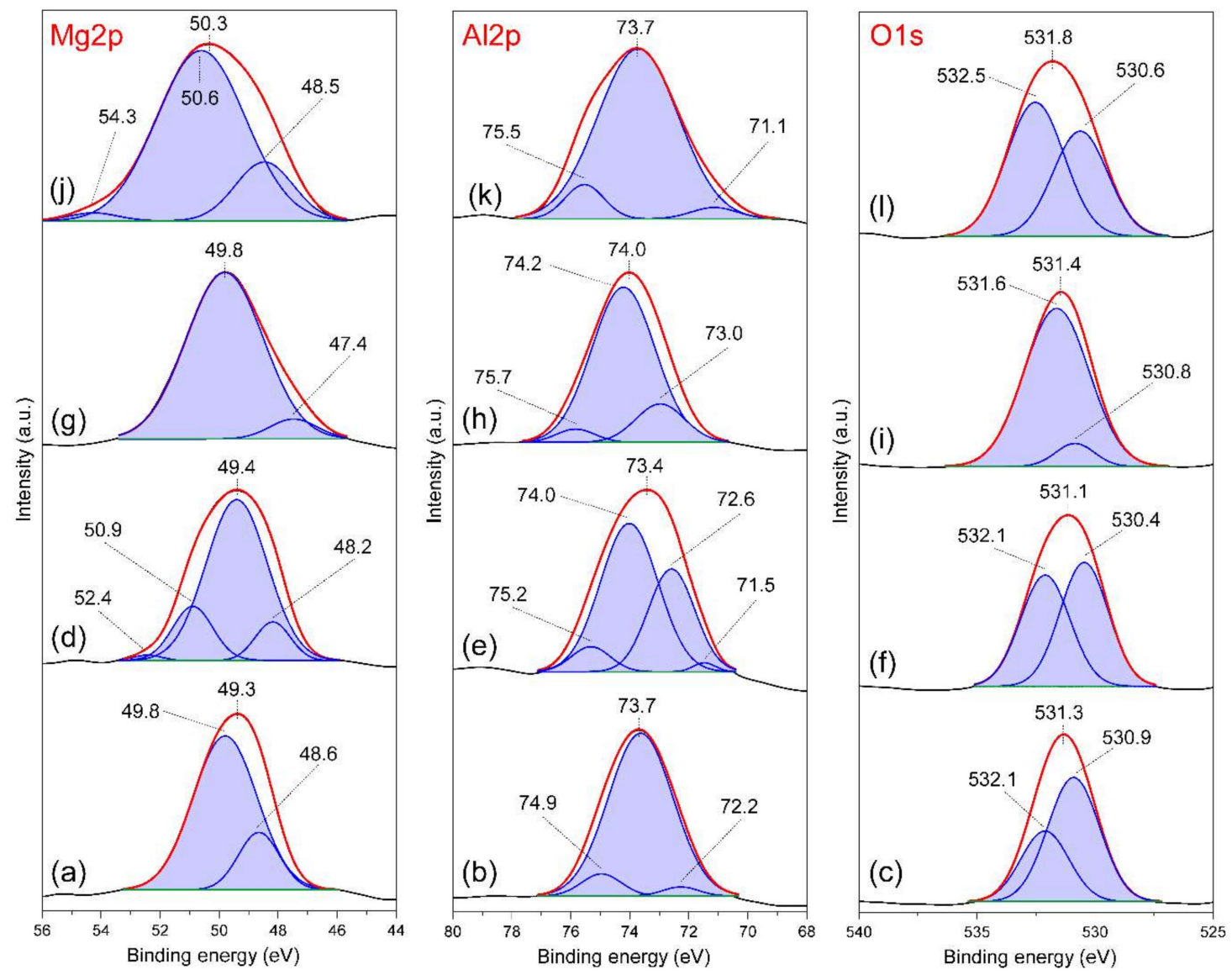

Figure 12. XPS Mg2s, Al2p and O1s spectra of: (a-c) Mg-Al-Cl-2 sample ( $\mathrm{pH} 7),(\mathbf{d}-\mathbf{f})$ FB1-treated Mg-Al-Cl-2 sample ( $\mathrm{pH} 7)$, (g-i) Mg-Al-Cl-2 sample ( $\mathrm{pH}$ 5), and ( $\mathbf{j}-\mathbf{1})$ FB1-treated $\mathrm{Mg}-\mathrm{Al}-\mathrm{Cl}-2$ sample ( $\mathrm{pH}$ 5).

\section{Conclusions}

The presented study investigated the affinity of chemically different LDH structures to fumonisin $\mathrm{B}_{1}$ mycotoxin. The $\mathrm{LDH}$ materials $(\mathrm{Mg} / \mathrm{Al}$ and $\mathrm{Mg} / \mathrm{Fe})$ with differing layer charges were synthesized by co-precipitation from both metal nitrates and chlorides. The adsorption experiments showed a clearly greater adsorption capacity for the $\mathrm{Mg} / \mathrm{Al} \mathrm{LDH}$ samples $(\sim 0.08-0.15 \mathrm{~mol} / \mathrm{kg})$ as compared to the $\mathrm{Mg} / \mathrm{Fe}$ LDH samples $(\sim 0.05-0.09 \mathrm{~mol} / \mathrm{kg})$. A significant difference in removal efficiency was not observed between chloride and nitrate intercalated LDH samples. However, a trend of increasing adsorption capacity along with higher $\mathrm{Mg} / \mathrm{Al}$ ratio (lower layer charge) was noticed. This was attributed to the lower content of bonded carbonates and increase of non-polar sites which led to matching between the adsorption domains of the LDH with the FB1 structure. For all the materials, a visibly greater adsorption was found for $\mathrm{pH}$ in the range of 4-5. The FTIR analysis allowed to confirm the negative effect of carbonates which hampered adsorption at $\mathrm{pH}$ 7. The highest adsorption capacity measured 
at $\mathrm{pH} 5$ corresponded to the FB1 content of $\sim 15.8 \pm 0.75 \mathrm{wt} . \%$. The kinetic experiment revealed fast adsorption with equilibrium achieved in the first 1-2 min. This suggested the external surface adsorption mechanism, which was confirmed by XRD results, which indicated that no FB1 intercalation occurred. The strong interaction of FB1 and LDH surface was confirmed by XPS technique for the samples equilibrated at different $\mathrm{pH}$ values. It was attested by the broadening and splitting of bands in the $\mathrm{Mg} 2 \mathrm{p}, \mathrm{Al} 2 \mathrm{p}$, and O1s spectra. In particular, the most significant distortion of $\mathrm{Mg}$ sites in the brucite-like layer was observed at $\mathrm{pH} 5$ where the interaction with $\mathrm{FB} 1$ carboxylate moieties $\mathrm{COO}^{-}$was confirmed. This research confirmed the high affinity and selectivity of LDH structures towards anionic forms of FB1 mycotoxin. The reported adsorption capacity was much higher than that determined for surfactant-modified zeolitic materials.

Supplementary Materials: The following are available online at http://www.mdpi.com/1996-1944/13/19/4344/s1, Figure S1: Particle size distribution of the raw LDH samples (y axis-Volume (\% a.u.)—one spacing on the y axis corresponds to $4 \%$ ).

Author Contributions: Conceptualization, J.M. and Y.D.; Funding acquisition, J.M.; Investigation, J.M.; Methodology, J.M. and Y.D.; Project administration, J.M.; Validation, J.M. and Y.D.; Visualization, J.M.; Writing, J.M.; Writing-review \& editing, J.M. and Y.D. All authors have read and agreed to the published version of the manuscript.

Funding: This research was funded by the AGH University of Science and Technology, grant number 16.16.140.315.

Acknowledgments: The research was conducted by Jakub Matusik at the Texas A\&M University (College Station, TX, USA) thanks to support from the Fulbright Scholar Program-Senior Award (2019/2020). The author is grateful for help and support from Texas A\&M faculty, staff and students: Youjun Deng, Audrey Girard, Bidemi Fashina and Chia-Wei Lin from Department of Soil and Crop Sciences and Jing Wu from Materials Characterization Facility. We are thankful to the NSF grant DBI0116835 which supported the acquisition of the FE-SEM.

Conflicts of Interest: The authors declare no conflict of interest.

\section{References}

1. Luo, Y.; Liu, X.; Li, J. Updating techniques on controlling mycotoxins-A review. Food Control 2018, 89, 123-132. [CrossRef]

2. Anater, A.; Manyes, L.; Meca, G.; Ferrer, E.; Luciano, F.B.; Pimpão, C.T.; Font, G. Mycotoxins and their consequences in aquaculture: A review. Aquaculture 2016, 451,1-10. [CrossRef]

3. Vila-Donat, P.; Marin, S.; Sanchis, V.; Ramos, A.J. A review of the mycotoxin adsorbing agents, with an emphasis on their multi-binding capacity, for animal feed decontamination. Food Chem. Toxicol. 2018, 114, 246-259. [CrossRef] [PubMed]

4. Avantaggiato, G.; Solfrizzo, M.; Visconti, A. Recent advances on the use of adsorbent materials for detoxification of Fusarium mycotoxins. Food Addit. Contam. 2005, 22, 379-388. [CrossRef] [PubMed]

5. Wang, M.; Maki, C.R.; Deng, Y.; Tian, Y.; Phillips, T.D. Development of High Capacity Enterosorbents for Aflatoxin B1 and Other Hazardous Chemicals. Chem. Res. Toxicol. 2017, 30, 1694-1701. [CrossRef]

6. Barrientos-Velázquez, A.L.; Marroquin Cardona, A.; Liu, L.; Phillips, T.; Deng, Y. Influence of layer charge origin and layer charge density of smectites on their aflatoxin adsorption. Appl. Clay Sci. 2016, 132-133, 281-289. [CrossRef]

7. Barrientos-Velázquez, A.L.; Arteaga, S.; Dixon, J.B.; Deng, Y. The effects of $\mathrm{pH}$, pepsin, exchange cation, and vitamins on aflatoxin adsorption on smectite in simulated gastric fluids. Appl. Clay Sci. 2016, 120, 17-23. [CrossRef]

8. Alam, S.S.; Deng, Y. Protein interference on aflatoxin B1 adsorption by smectites in corn fermentation solution. Appl. Clay Sci. 2017, 144, 36-44. [CrossRef]

9. Gan, F.; Hang, X.; Huang, Q.; Deng, Y. Assessing and modifying China bentonites for aflatoxin adsorption. Appl. Clay Sci. 2019, 168, 348-354. [CrossRef]

10. Yuan, X.; Jing, Q.; Chen, J.; Li, L. Photocatalytic Cr(VI) reduction by mixed metal oxide derived from ZnAl layered double hydroxide. Appl. Clay Sci. 2017, 143, 168-174. [CrossRef]

11. Mishra, G.; Dash, B.; Pandey, S. Layered double hydroxides: A brief review from fundamentals to application as evolving biomaterials. Appl. Clay Sci. 2018, 153, 172-186. [CrossRef] 
12. Mohapatra, L.; Parida, K. A review on the recent progress, challenges and perspective of layered double hydroxides as promising photocatalysts. J. Mater. Chem. A 2016, 4, 10744-10766. [CrossRef]

13. Huang, P.-P.; Cao, C.-Y.; Wei, F.; Sun, Y.-B.; Song, W.-G. MgAl layered double hydroxides with chloride and carbonate ions as interlayer anions for removal of arsenic and fluoride ions in water. RSC Adv. 2015, 5, 10412-10417. [CrossRef]

14. Jawad, A.; Peng, L.; Liao, Z.; Zhou, Z.; Shahzad, A.; Ifthikar, J.; Zhao, M.; Chen, Z.; Chen, Z. Selective removal of heavy metals by hydrotalcites as adsorbents in diverse wastewater: Different intercalated anions with different mechanisms. J. Clean. Prod. 2019, 211, 1112-1126. [CrossRef]

15. Zubair, M.; Daud, M.; McKay, G.; Shehzad, F.; Al-Harthi, M.A. Recent progress in layered double hydroxides (LDH)-containing hybrids as adsorbents for water remediation. Appl. Clay Sci. 2017, 143, 279-292. [CrossRef]

16. Chubar, N.; Gilmour, R.; Gerda, V.; Micusik, M.; Omastova, M.; Heister, K.; Man, P.; Fraissard, J.; Zaitsev, V. Layered double hydroxides as the next generation inorganic anion exchangers: Synthetic methods versus applicability. Adv. Colloid Interface Sci. 2017, 245, 62-80. [CrossRef] [PubMed]

17. Forano, C.; Costantino, U.; Prévot, V.; Gueho, C.T. Layered Double Hydroxides (LDH). In Developments in Clay Science; Bergaya, F., Lagaly, G., Eds.; Elsevier: Amsterdam, The Netherlands, 2013; Volume 5, pp. 745-782.

18. Goh, K.H.; Lim, T.T.; Dong, Z. Application of layered double hydroxides for removal of oxyanions: A review. Water Res. 2008, 42, 1343-1368. [CrossRef]

19. Olszówka, J.E.; Karcz, R.; Bielańska, E.; Kryściak-Czerwenka, J.; Napruszewska, B.D.; Sulikowski, B.; Socha, R.P.; Gaweł, A.; Bahranowski, K.; Olejniczak, Z.; et al. New insight into the preferred valency of interlayer anions in hydrotalcite-like compounds: The effect of Mg/Al ratio. Appl. Clay Sci. 2018, 155, 84-94. [CrossRef]

20. Dakovic, A.; Kragovic, M.; Rottinghaus, G.E.; Sekulic, Z.; Milicevic, S.; Milonjic, S.K.; Zaric, S. Influence of natural zeolitic tuff and organozeolites surface charge on sorption of ionizable fumonisin $\mathrm{B}_{1}$. Colloids Surf. B Biointerfaces 2010, 76, 272-278. [CrossRef]

21. Daković, A.; Tomašević-Čanović, M.; Rottinghaus, G.E.; Matijašević, S.; Sekulić, Ž. Fumonisin B1 adsorption to octadecyldimethylbenzyl ammonium-modified clinoptilolite-rich zeolitic tuff. Microporous Mesoporous Mater. 2007, 105, 285-290. [CrossRef]

22. Cavani, F.; Trifirò, A.V.; Vaccari, A. Hydrotalcite-type anionic clays: Preparation, properties and application. Catal. Today 1991, 11, 171-301. [CrossRef]

23. Drits, V.A.; Bookin, A.S. Crystal structure and X-Ray Identification of Layered Double Hydroxides. In Layered Double Hydroxides: Present and Future; Rives, V., Ed.; Nova Science Publishers: Hauppauge, NY, USA, 2001; pp. 41-101.

24. Wang, S.-L.; Wang, P.-C. In situ XRD and ATR-FTIR study on the molecular orientation of interlayer nitrate in Mg/Al-layered double hydroxides in water. Colloids Surf. A 2007, 292, 131-138. [CrossRef]

25. Xu, Z.P.; Zeng, H.C. Abrupt Structural Transformation in Hydrotalcite-like Compounds $\mathrm{Mg}_{1-\mathrm{x}} \mathrm{Al}_{\mathrm{x}}(\mathrm{OH})_{2}\left(\mathrm{NO}_{3}\right)_{\mathrm{x}} \cdot \mathrm{nH}_{2} \mathrm{O}$ as a Continuous Function of Nitrate Anions. J. Phys. Chem. B 2001, 105, 1743-1749. [CrossRef]

26. Di Cosimo, J.I.; Díez, V.K.; Xu, M.; Iglesia, E.; Apesteguía, C.R. Structure and Surface and Catalytic Properties of Mg-Al Basic Oxides. J. Catal. 1998, 178, 499-510. [CrossRef]

27. Kloprogge, J.T.; Wharton, D.; Hickey, L.; Frost, R.L. Infrared and Raman study of interlayer anions $\mathrm{CO}_{3}{ }^{2-}$, $\mathrm{NO}_{3}{ }^{-}, \mathrm{SO}_{4}{ }^{2-}$, and $\mathrm{ClO}_{4}{ }^{-}$in $\mathrm{Mg} / \mathrm{Al}$-hydrotalcite. Am. Mineral. 2002, 87, 623-629. [CrossRef]

28. Momany, F.A.; Dombrink-Kurtzman, M.A. Molecular dynamics simulations on the mycotoxin fumonisin B1. J. Agric. Food Chem. 2001, 49, 1056-1061. [CrossRef]

29. Beier, R.C.; Stanker, L.H. Molecular models for the stereochemical structures of fumonisin B1 and B2. Arch. Environ. Contam. Toxicol. 1997, 33, 1-8. [CrossRef]

30. Matusik, J.; Hyla, J.; Maziarz, P.; Rybka, K.; Leiviska, T. Performance of Halloysite-Mg/Al LDH Materials for Aqueous As(V) and Cr(VI) Removal. Materials 2019, 12, 3569. [CrossRef]

31. Hsu, C.C. Selecting and Modifying Smectites and Layered Double Hydroxides to Bind Fumonisin B1, Ochratoxin A, Zearalenone, and Deoxynivalenol. Ph.D. Thesis, Department of Soil and Crop Sciences, Texas A \& M University, College Station, TX, USA, 2018.

32. Beier, R.C.; Elissalde, M.H.; Stanker, L.H. Calculated three-dimensional structures of the fumonisin $B_{1-4}$ mycotoxins. Bull. Environ. Conam. Toxicol. 1995, 54, 479-487. [CrossRef] 
33. Matusik, J. Arsenate, orthophosphate, sulfate, and nitrate sorption equilibria and kinetics for halloysite and kaolinites with an induced positive charge. Chem. Eng. J. 2014, 246, 244-253. [CrossRef]

34. Chubar, N.; Gerda, V.; Megantari, O.; Mičušík, M.; Omastova, M.; Heister, K.; Man, P.; Fraissard, J. Applications versus properties of $\mathrm{Mg}-\mathrm{Al}$ layered double hydroxides provided by their syntheses methods: Alkoxide and alkoxide-free sol-gel syntheses and hydrothermal precipitation. Chem. Eng. J. 2013, 234, 284-299. [CrossRef]

35. Haycock, D.E.; Kasrai, M.; Nicholls, C.J.; Urch, D.S. The electronic structure of magnesium hydroxide (brucite) using X-ray emission, X-ray photoelectron, and auger spectroscopy. J. Chem. Soc. Dalton Trans. 1978, 12, 1791-1796. [CrossRef]

36. Zhang, F.; Zhang, C.-L.; Song, L.; Zeng, R.-C.; Cui, L.-Y.; Cui, H.-Z. Corrosion Resistance of Superhydrophobic $\mathrm{Mg}-\mathrm{Al}$ Layered Double Hydroxide Coatings on Aluminum Alloys. Acta Metall. Sin. Engl. Lett. 2015, 28, 1373-1381. [CrossRef]

37. Jerome, R.; Teyssie, P.; Pireaux, J.J.; Verbist, J.J. Surface analysis of polymers end-capped with metal carboxylates using X-ray photoelectron spectroscopy. Appl. Surf. Sci. 1986, 27, 93-105. [CrossRef]

(C) 2020 by the authors. Licensee MDPI, Basel, Switzerland. This article is an open access article distributed under the terms and conditions of the Creative Commons Attribution (CC BY) license (http://creativecommons.org/licenses/by/4.0/). 